\title{
A Survey on Cost Effective Survivable Network Design in Wireless Access Network
}

\author{
K.Rajalakshmi and Krishna Gopal \\ Department of Computer Science, Jaypee Institute of Information Technology, Noida
}

\begin{abstract}
In today's technology, the essential property for wireless communication network is to exhibit as a dependable network. The dependability network incorporates the property like availability, reliability and survivability. Although these factors are well taken care by protocol for wired network, still there exists huge lack of efficacy for wireless network. Further, the wireless access network is more complicated with difficulties like frequencies allocation, quality of services, user requests. Adding to it, the wireless access network is severely vulnerable to link and node failures. Therefore, the survivability in wireless access network is very important factor to be considered will performing wireless network designing. This paper focuses on discussion of survivability in wireless access network. Capability of a wireless access network to perform its dedicated accessibility services even in case of infrastructure failure is known as survivability. Given available capacity, connectivity and reliability the survivable problem in hierarchical network is to minimize the overall connection cost for multiple requests. The various failure scenario of wireless access network as existing in literature is been explored. The existing survivability models for access network like shared link, multi homing, overlay network, sonnet ring, and multimodal devices are discussed in detail here. Further comparison between various existing survivability solutions is also tabulated.
\end{abstract}

\section{KEYWORDS}

survivability, cost, capacity, optimization, wireless access network.

\section{Introduction}

Rapidly growing wireless network and increasing demands mobile communication attracts research and development with emphasis on mobile data services. In current scenarios, the mobile users utilize untethered access to wireless network resources. Wireless access network includes personal communication services (PCS), cellular network and wireless local area networks (WLAN). Wireless networks are more attractive in spite of low quality and reduced services than wired networks. Research in wireless access network is to provide communication services at "any time, any place, any form". The vision of wireless access network is to provide services like voice, data and multimedia to the users regardless of location, user mobility and type of access terminal used. Users demand reliable services similar to wired telecommunication and data networks which lead to intolerance to communication failure or critical data loss. Ability of a network to perform its intended services upon infrastructure component failures is known as survivability. Survivability is achieved by simple fault tolerance future. Failures occurs in components like switches, base stations, databases, mobile devices, wired / wireless links among mobile terminal, base station, switches. Wireless access network has tree like topology, is very 
International Journal of Computer Science \& Engineering Survey (IJCSES) Vol.5, No.1, February 2014

much vulnerable to failures. The nodes of the access network topology are BSs, BSCs, and MSCs. The link or edges of topology are the physical transmission cables that establish communication between nodes. Two types of failures occur in wireless access network, they are node failure and link failure. Thus, survivability of the network in case of failure must be addressed while designing access network. Even a single link failure could cost heavy damage to the network services. Especially loss of critical communication cannot be tolerated and need an effective restoration mechanism.

A generic wireless access network consists of cells base station, base station controllers and mobile switch centers. Geographical service area of cellular network is partitioned into small structures called cells. Each cell has a fixed base station which is access points for all mobile terminals (MTs). Base station controller (BSC) manages group of Base stations (BSs). The wireless links between the BS and MTs within cells are digital and employ time division multiple access (TDMA) or spread spectrum code division multiple access (CDMA). BSs and BSCs are connected to backbone network via Mobile switching centers (MSC). MSCs are connected to the core network through access routers. Mobile switching center connects to the signaling network further through transmission network. Associated with signaling network and MSCs are databases that support users with service mobility like authentication and roaming. In general wireless access network is associated with Home Location Register (HLR), Visitor Location Register (VLR), Equipment Identity Registers (EIR) and Authentication centers (AUCs). The home location register provides user profile information like types of services subscribed, billing information and location information. The visitors' location register provides information about the mobile user's visiting an associated MSC coverage area. Figure 1 depicts, various three level of wireless access network namely BS level, BSC level and MSC level. At BS level the mobile terminals communicate to their corresponding cell BSs. At BSC level, BSs connects to their allocated BSCs. And at the MSC level BSCs connect to their corresponding MSCs. The communication link between the BS, BSC and MSC are typically wire line or fixed microwave links.

As given by Kubat et al. in [2] and also in [7], the cells originating and/or terminating at the mobile units are connected to a cell site over a radio link (analog, digital). From the cell, the call proceeds to the MSC for processing and switching. The switch transfers the call to its destination - either another mobile unit, or to a PSTN for delivery to a wired telephone terminal. Between the cell site and the MSC, the connection is over terrestrial, T1 digital transmission lines or over private digital microwave.

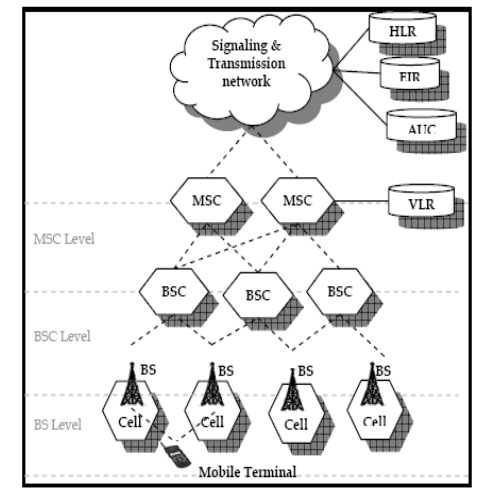

Fig 1. A basic wireless access network 
International Journal of Computer Science \& Engineering Survey (IJCSES) Vol.5, No.1, February 2014

As stated by Houeto et al. [5], generally three types of networks are distinguished in the $3 \mathrm{G}$ wireless networks. The core network is a WAN or a MAN, whereas the access networks or LAN or WLAN which essentially consist of access routers (AR), hubs and Multiplexers. An access network can have a star, tree, ring or mesh topology. In star topology; central master node controls all the auxiliary nodes. The auxiliary nodes must communicate each other only through the central master node. In case of tree topology; the principal node is the root node through which all the communications takes place. The tree topology is a hierarchical structure with child nodes. In case of ring topology, the nodes are connected in a point to point to form are further interconnected to form a ring. Considering two nodes, they perform point to point communication whereas a whole network, the nodes form ring topology. In case of fully meshed topology, each node is connected to every other node. In partially meshed topology, each node is connected to more than one node.

\section{Need for survivability}

The major objective to achieve end-end performance of networks and systems is dependability. The dependable networks are valued based on three parameters namely reliability, survivability and availability. Reliability is defined as the estimation of network failure probability. The probability is measured using mean time between failures (MTBF). Availability is defined as the estimation of network ready time for usage without any interference. The parameters like mean time to repair, mean time between failures are used to estimate the availability. The objective of availability is to achieve faster MTR and lesser MTBF which will improve the performance tremendously. Survivability is defined as the ability of network to perform its assigned function even during the event of failures of network components. The dependability in wired network like local area network, wide area network have gained performance enhancement in recent years. Further high speed networks like public switched network, internet, ATM, frame relay are been researched very well. However, in case of wireless network, dependability is still requires many issues to be addressed. One such essential parameter to be address in wireless network performance is fault tolerance in the network components.

Varshney [3][6] discusses one of the major reasons for targeting survivability problem is to develop an efficient dependable wired network. The dependable wired network incorporates all three properties like Reliability, Availability and Survivability. Some dependable networks like internet, public switched networks, ATM based networks although lacks proper enhancement towards reliability, survivability and availability but has achieved these requirements to some extent. However, the wireless networks lacks tremendous by the factors of survivability, reliability and availability. The factors affecting these enhancements are diverse link types for wireless medium like Bluetooth, Zigbee, RF etc, further adding to this are the factors like user mobility, lack of regulations, high CAPAX and OPEX for wireless access networks. Also due to technologies diversities like GSM, UMTS, CDMA, 3G LTE environments, the performance of such wireless networks degrades.

Some of notable recent works are discussed further. Oriol et al [8] provided a roadmap for UMTS optimization and illustrated a methodology to provide sub optimal coverage of cells. Gordejuela et al., [9] described a way to deal with the tradeoff generated during the LTE access network design, and presented a service oriented optimization framework that would offer a new perspective considering technical and economical factor of cellular network. Quintero et al. [10] targeted assignment of NodeBs to RNCs in large scale 3G cellular networks. Hybrid genetic 
International Journal of Computer Science \& Engineering Survey (IJCSES) Vol.5, No.1, February 2014

algorithm with migration was used to solve the NP hard problem. The authors propose multi population approach where each population was partitioned into subpopulations. These works further neccesiaties the research foucs on the end-end performance of wireless networks.

\section{Failure Scenarios}

Survivability strategies designed and analyzed for wired networks are not applicable for the wireless network, major reasons being the user mobility and power management in the wireless network. The end to end performance of wireless network is fully graded based on the user mobility and power management. In order to facilitate survivable analysis and design of wireless access networks, Tipper et al. [1] developed a survivability framework similar to the approaches for wired backbone networks. The survivability framework for wireless access networks consists of three layers with survivability strategies possible at each layer. The three layers are termed access, transport, and intelligent. Note that the logical layers defined here are independent of the physical implementation of the network. Each of the three layers is characterized by network functions, network components, and communication links.

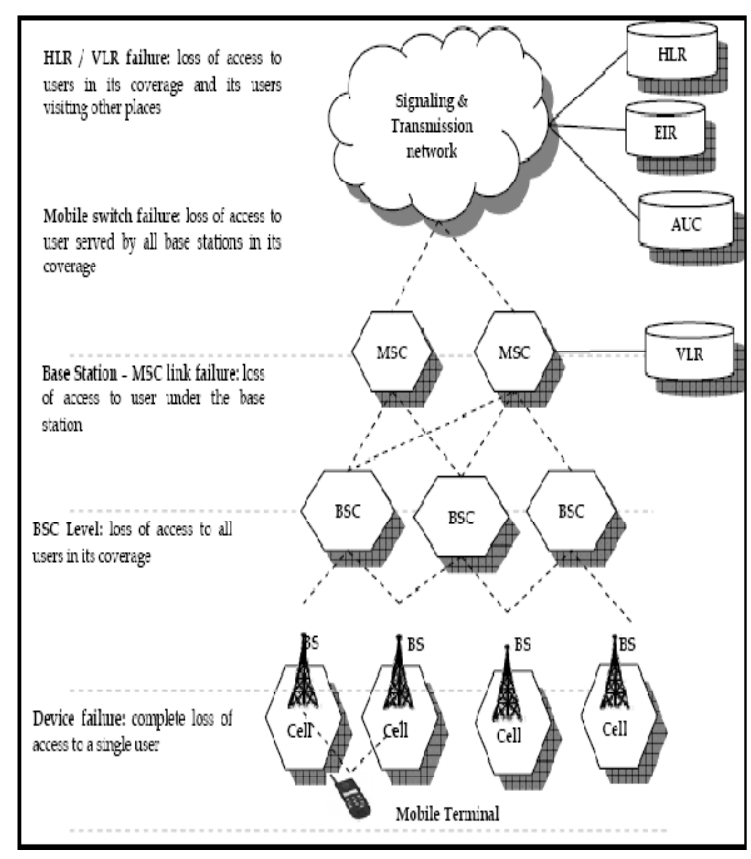

Fig 2. Failures in wireless networks

Generic example of failure scenarios in cellular / PCS network are (i) failure of a base station (ii) loss of a mobile switching centre (iii) loss of link between a base station and a mobile switching center. Metrics used to access survivability of network (i) Network performance using call blocking probability (ii) traffic restoration efficiency based on percentage of failed demand been restored. The failure of the wireless network components can affect the performance of networks in several ways. 
International Journal of Computer Science \& Engineering Survey (IJCSES) Vol.5, No.1, February 2014

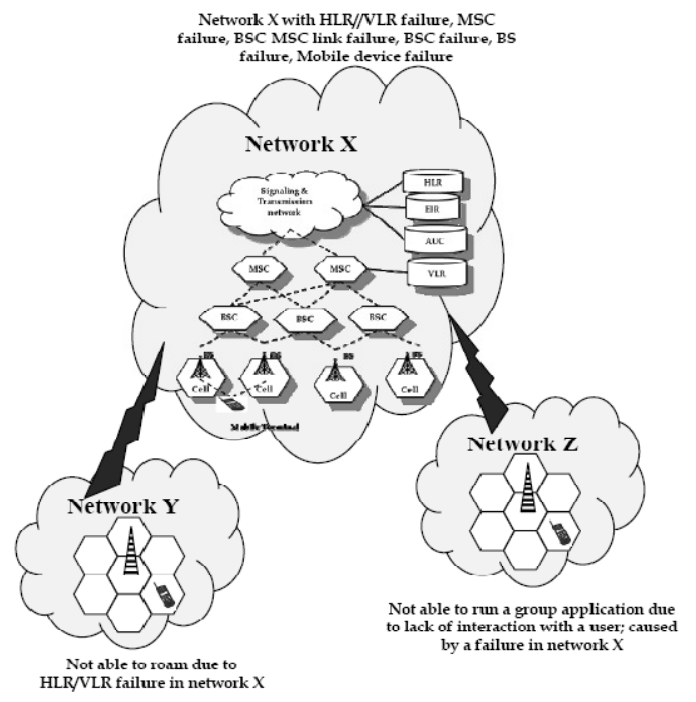

Figure 3. Impact of failures in inter communication between wireless cellular networks

This is illustrated using figure 3. Network $\mathrm{X}$ failure may occur due to any of the failures such as MSC failure, BSC/BS failure, link failure and HLR/VLR failure. When such failure occur in network $\mathrm{X}$, the customer belonging to network $\mathrm{Y}$ is not able to access the roaming facilities of network X. Similarly, considering network Z, utilizing group membership facility of network X, but then as the network $X$ fails due to various failure scenario, the group services are not available for the network $\mathrm{Z}$.

\section{Survivable Strategies}

Kubat et al. [2] and Dutta et al. [7] models the network design of cellular network as (i) Model \#1 is a 1-period fixed-link capacity model (ii) Model \#2 allows the capacities of the links to vary (iii) Model \#3 presents a multi-period demand problem. In this, ring type of network topology is consider as restriction and analysis of optimal homing of the network nodes are been carried out. Here each cell can home multi-homing. That is, the cells can be connected to different nodes. The major restriction is that each of these nodes has to be on different disjoined trees. The above restriction adds complexity to the network designing. By varying the capacity of links connecting the nodes with each other, the performance has been evaluated. Considering the traffic flow, the traffic comprises of cellular traffic and backbone traffic. The backbone traffic constitutes the major traffic part the access network. Therefore, while performing network designing this diversified load on the transmission link must be consider. Varshney et al. [3] [6] presents a network design scheme using 'selective' multilevel fault tolerance for dependable infrastructureoriented wireless networks. The selective multi-level fault tolerance incorporates adaptable building blocks (ABB). The diversified dependable networks with criteria like survivability, reliability and availability are targeted by ABB using several levels of repairs in order to reduce redundancy of network components. Te various levels of possible repairs are at switches, base stations, BS controllers, and HLR and VLR databases. Tipper et al. [1] applies survivability strategies at three different layers namely (1) at access layer (2) at transport layer (3) at intelligent layer. At the radio level of access layer, the wireless link failure to the user is the primary failure. To provide survivability during link failure, each base station supports two types of radio 
International Journal of Computer Science \& Engineering Survey (IJCSES) Vol.5, No.1, February 2014

channels namely short haul and long haul channel. The short haul channel is active within the same cell site. The long haul channel is active in larger circle. The disadvantage of such dual link is interference due to co channel problem. The second level of failure at transport layer is caused due to link or component breakdown. This can be overcome by using mesh type of architecture at the access layer, self healing dual rings and automated switch protection. Finally, at the top intelligent layer, the important components constitute system databases like home location register (HLR) and visitor location register (VLR). The survivable strategies must be implemented in order to overcome the failures at system databases. The techniques like distributed databases, breakpoint strategy in protocol, and backup standby databases are recommended for robustness against failure at intelligent layer system databases. Houteo et al. [4] analyze the reliability aspects of access network topologies ensure QoS with lowest cost for end users. Three access network topologies are studied: the tree with parallel back up links, the ring and the partially meshed topologies. The study establishes (i) the cost as a function of the quality of service (ii) optimizes the partially meshed topology for more reliable networks (iii) define a shaping policy to deal with variety of traffic schemes. To provide survivability in cellular access network, Snow et al [4] proposed solution at architectural level like sonnet ring, devices with multiple modes of operations and overlay networks. Sonnet Rings: Sonnet ring inhibits ring architecture with dual rings. In case of single link cut or single transmitter/receiver failure, the backup ring tolerates such failure as it is further connected to multiple links. Sonnet rings, target to provide end-to-end reliability by adding redundancy. The telephone switched network is connected with multiple base stations for same cell site area by using sonnet rings that readily fault tolerant. Multimode devices: Snow et al further suggest devices with multiple functionalities or with different modes of operation to tolerate the network failures, thus the device enhances its performance by improving survivability in the wireless access network. The survivability is achieved in multimodal devices by overlapped services provided while designing architecture. This overlapped service ensures wireless coverage in case of link or node failure in the access network. Thus this method impacts the performance in an effective manner, by increasing the coverage area even during failure.Overlay network architecture: The overlay network consists of several access points available universally to all users. The key role of universal access point is to provide frequency assignment for requesting user, protocol management and content adaptation. A user in an overlay network can access these access points. In turn user is connected to wireless network depending on availability of frequency, user specific services and type of quality required by users.

\section{Conclusion}

Although dependability factors like reliability, survivability, availability is taken care very well for wired networks; there exists deficiency in wireless networks. The complexity in wireless network is due to signal propagation, bandwidth limitation, quality of service, on demand user request. Adding to this, the serious problem of tolerance to link and node failures within access network exists. The various failure scenario and important survivability mechanism of wireless access network as existing in literature has been explored in this paper. The survivability models for like shared link, multi homing, overlay network, sonnet ring, and multimodal devices are discussed in detail here. Table 2 provides review of five different papers based on parameters like theoretical base, sample choice and tests. Theoretical base desires the broad base on fundaments and whether all the important theories are considered. Sample choice depicts adequate size and consistence within the samples. Test illustrates the suitability and supported arguments. 
International Journal of Computer Science \& Engineering Survey (IJCSES) Vol.5, No.1, February 2014

Timeliness meant for technology advancement. Limitations must be state clearly without harming the applicability of the problem stated.

Table 2 Consolidated Survey of Research Papers

\begin{tabular}{|c|c|c|c|c|c|c|}
\hline S1 & Journal Title & Article & Theoretical Base & $\begin{array}{l}\text { Tests \& Sample } \\
\text { choice }\end{array}$ & Limnitations & Future Scope \\
\hline 1 & $\begin{array}{l}\text { IEEE } \\
\text { Comnunications } \\
\text { Magazine }\end{array}$ & $\begin{array}{ll}\text { D.Tipper, } & \text { T. } \\
\text { Dalhberg, H. } \\
\text { Shin, "Providing } \\
\text { Fault Tolerance in } \\
\text { Wireless Access } \\
\text { Networks, vol. 40, } \\
\text { no.1, pp, } 58.64 \text {, } \\
\text { January 2002. }\end{array}$ & $\begin{array}{l}\text { basics concerning } \\
\text { survivability in the } \\
\text { wireless } \\
\text { telecommunication } \\
\text { networks; limited } \\
\text { references - } 12 \\
\text { research papers }\end{array}$ & $\begin{array}{l}\text { simulation based } \\
\text { and discussed in } \\
\text { short; random } \\
\text { distributions are } \\
\text { used. number of } \\
\text { subscribers } \\
1,00,000 ; \text { number of } \\
\text { cells per mobile } \\
\text { switch center }=100\end{array}$ & $\begin{array}{l}\text { single objective } \\
\text { of cost } \\
\text { optimization } \\
\text { and } \\
\text { survivability; } \\
\text { each user of the } \\
\text { failed } \\
\text { connections } \\
\text { attempts to } \\
\text { reconnect only } \\
\text { one time. }\end{array}$ & $\begin{array}{l}\text { Limited discussion } \\
\text { on future scope; } \\
\text { future scope to } \\
\text { address } 2.5 \mathrm{~S} \text { and } \\
3 \mathrm{G} \text { networks. }\end{array}$ \\
\hline 2 & $\begin{array}{l}\text { IFFE } \\
\text { Transaction on } \\
\text { Reliability }\end{array}$ & $\begin{array}{l}\text { P. Kulbat, I M } \\
\text { Smith, and C. } \\
\text { Yum, "Design of } \\
\text { Cellular Networks } \\
\text { with Diversity and } \\
\text { Capacity } \\
\text { Constraints," vol. } \\
49, \text { no. 2, pp. 165- } \\
175, \text { June 2000. }\end{array}$ & $\begin{array}{l}\text { mathematical } \\
\text { modeling of network } \\
\text { design of cellular } \\
\text { network } \\
\text { description abort } \\
\text { literature survey. }\end{array}$ & $\begin{array}{l}\text { simmilation based } \\
\text { and discussed in } \\
\text { short less number } \\
\text { of cells }=12 \text {, } \\
\text { sample size not } \\
\text { defined properly. }\end{array}$ & $\begin{array}{l}\text { mintiple period } \\
\text { demand, } \\
\text { variable link } \\
\text { capacity } \\
\text { problem are not } \\
\text { targeted. }\end{array}$ & $\begin{array}{l}\text { Mix of finite and } \\
\text { infinite capacities } \\
\text { on link, and } \\
\text { incorporating link } \\
\text { costs; to address as } \\
\text { a stenier problem }\end{array}$ \\
\hline 3 & $\begin{array}{l}\text { International } \\
\text { Journal of } \\
\text { Network } \\
\text { Management }\end{array}$ & $\begin{array}{l}\text { U. Varshney and } \\
\text { A D M Malloy, } \\
\text { "Multilevel Fault } \\
\text { Tolerance in } \\
\text { Infrastructure- in } \\
\text { Oriented Wireless } \\
\text { Networks: } \\
\text { Framework and } \\
\text { Performance and } \\
\text { Evaluation," vol. } \\
16 \text {, no. S, pp. } 351- \\
374 \text {, February } \\
2006 \text {. }\end{array}$ & $\begin{array}{l}\text { wel1 defined fault- } \\
\text { tolerant architecture } \\
\text { for interconnection } \\
\text { of wireless cellular } \\
\text { network building } \\
\text { blocks refers } 40 \\
\text { research papers }\end{array}$ & $\begin{array}{l}\text { Cl+ based } \\
\text { simulation mode1; } \\
\text { discussed in details. } \\
\text { varying sample size } \\
\text { from } 1000-100000 \\
\text { subscribers; base } \\
\text { station } 356 \text { to } 2000\end{array}$ & $\begin{array}{l}\text { Without cost } \\
\text { evaluation; user } \\
\text { mobility, } \\
\text { multiple } \\
\text { diverged } \\
\text { wireless link, } \\
\text { adhoc network } \\
\text { not included }\end{array}$ & $\begin{array}{l}\text { to include cost } \\
\text { benefit model; } \\
\text { interconnection } \\
\text { network }\end{array}$ \\
\hline 4 & $\begin{array}{l}\text { IEEE } \\
\text { Transaction on } \\
\text { Reliability }\end{array}$ & $\begin{array}{l}\text { Fi Houeto, S. } \\
\text { Pierre. } \\
\text { Beaubrun, and } \mathrm{R} \\
\text { Lemieux, } \\
\text { "Reliability and } \\
\text { Cast Evaluation of } \\
\text { Third-Generation } \\
\text { Wireless Access } \\
\text { Network } \\
\text { Topologies: A } \\
\text { Case Study," vol. } \\
51 \text {, no. 2, pp. 229- } \\
\text { 239. June 2002. }\end{array}$ & $\begin{array}{l}\text { concerns reliable, } \\
\text { cost effective access } \\
\text { network topologies; } \\
\text { address certain } \\
\text { quality of services at } \\
\text { low cost for the end } \\
\text { users. }\end{array}$ & $\begin{array}{l}\text { simulation based; } \\
\text { uses real } \\
\text { equipments cost in } \\
\text { dollar, number of } \\
\text { users vary from } 100 \\
\text { to } 500 \text { per switch. }\end{array}$ & $\begin{array}{l}\text { each } \\
\text { transceiver set } \\
\text { can handle only } \\
100 \text { users; } \\
\text { initial cost } \\
\text { depends on the } \\
\text { topology } \\
\text { chosen }\end{array}$ & $\begin{array}{l}\text { To extend it to } 3 G \\
\text { technology which } \\
\text { supports up to } 500 \\
\text { users } \quad \text { per } \\
\text { transceiver set }\end{array}$ \\
\hline 5 & IIEEE Computer & 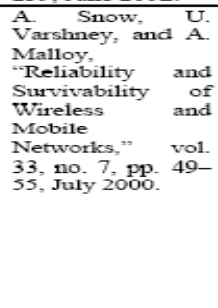 & $\begin{array}{l}\text { proposes various } \\
\text { architectural changes } \\
\text { to overcome current } \\
\text { outage problem in } \\
\text { wireless access } \\
\text { networks. }\end{array}$ & 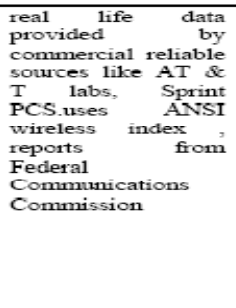 & $\begin{array}{l}\text { redundancy in } \\
\text { access and } \\
\text { radio links, but } \\
\text { it is typically } \\
\text { not done due to } \\
\text { cost and limited } \\
\text { frequency } \\
\text { spectrum }\end{array}$ & $\begin{array}{l}\text { in addition to } \\
\text { making wireless } \\
\text { networks more } \\
\text { survivable, the } \\
\text { engineering } \\
\text { and operational } \\
\text { goals of the } \\
\text { surviving carriers } \\
\text { should focus on } \\
\text { providing end-to } \\
\text { end service for } \\
\text { voice } \\
\text { and data mobile } \\
\text { users in a mixed } \\
\text { wireline/wireless } \\
\text { infrastructure }\end{array}$ \\
\hline
\end{tabular}

\section{References}

[1] D.Tipper, T. Dalhberg, H. Shin, "Providing Fault Tolerance in Wireless Access Networks," IEEE Communications Magazine, vol. 40, no.1, pp. 58-64, January 2002.

[2] P.Kubat, J. M. Smith, and C. Yum, "Design of Cellular Networks with Diversity and Capacity Constraints," IEEE Transaction on Reliability, vol. 49, no. 2, pp. 165-175, June 2000.

[3] U.Varshney and A. D. Malloy, "Multilevel Fault Tolerance in Infrastructure-Oriented Wireless Networks: Framework and Performance Evaluation,” International Journal of Network Management, vol. 16, no. 5, pp. 351-374, February 2006.

[4] F. Houeto, S. Pierre, R. Beaubrun, and Y. Lemieux, "Reliability and Cost Evaluation of ThirdGeneration Wireless Access Network Topologies: A Case Study," IEEE Trans. On Reliability, vol. 51, no. 2, pp. 229-239, June 2002.

[5] A.Snow, U. Varshney, and A. Malloy, "Reliability and Survivability of Wireless and Mobile Networks," IEEE Computer, vol. 33, no. 7, pp. 49-55, July 2000.

[6] U.Varshney, R. Vetter, "Emerging mobile and wireless networks," Communications of the ACM, vol. 43 no. 6 pp. $73-81.2000$. 
International Journal of Computer Science \& Engineering Survey (IJCSES) Vol.5, No.1, February 2014

[7] A. Dutta, P. Kubat, "Design of partially survivable networks for cellular telecommunication systems," European Journal of Operational Research vol. 118, pp. 52-64, 1999.

[8] Oriol Sallen, et al., "A Roadmap from UMTS Optimization to LTE Self-Optimization", IEEE Communications Magazine, pp 172-182, June 2011.

[9] F. Gordejuela-Sanchez and J. Zhang, "LTE Access Network Planning and Optimization: A ServiceOriented and Technology-Specific Perspective," IEEE Global Communications Conference (GLOBECOM'09), Honolulu, Hawaii, USA, December 2009.

[10] A. Quintero, S. Pierre , "On the Design of Large-Scale UMTS Mobile Networks Using Hybrid Genetic Algorithms”, IEEE Trans On Vehicular Technology, vol. 57, no. 4. pp. 2498-2508, 2008. 